Ann. Parasitol. Hum. Comp., 1992, 67: ${ }^{\circ} 6,194-196$.

Mémoire.
Key-words: Human onchocerciasis. Ivermectin. Mode of action. Pre-lymphatic capillaries. Intralymphatic microfilariae.

Mots-clés : Onchocercose humaine. Ivermectine. Mode d'action. Lymphatiques initiaux. Microfilaires intra-lymphatiques.

\title{
IVERMECTIN IN HUMAN ONCHOCERCIASIS: A CLINICAL-PATHOLOGICAL STUDY OF SKIN LESIONS BEFORE AND THREE DAYS AFTER TREATMENT ${ }^{1}$
}

\author{
P. N. VUONG *, S. TRAORÉ**, S. WANJI***, S. DIARRASSOUBA**, \\ A. BALATON*, O. BAIN ***
}

\begin{abstract}
SUMMARY
Findings are presented from an histological study of 360 skinsnips (from iliac crests, calves, ankles) taken from 30 Ivory Coast onchocerciasis patients before and three days after an oral dose of ivermectin $(200 \mu \mathrm{g} / \mathrm{kg})$. This dose causes a nearly complete disappearance of the intralymphatic microfilariae and, surprisingly, of the " extra-vascular " ones. That shows the difficulty to localize the microfilariae on histological sections; these microfilariae are in fact inside the lymphatic pre-capillaries.
\end{abstract}

There was no intensification of acute skin lesions after the treatment, thus showing that, contrary to diethylcarbamazin (DEC), ivermectin does not induce an exit of microfilariae into the extralymphatic connective tissue. Under the influence of ivermectin, paralyzed microfilariae may be carried passively towards the deep sub-cutaneous lymphatics, and then destroyed inside the regional lymph nodes, without producing major changes in the skin.

Résumé : Onchocercose humaine et ivermectine : étude anatomo-clinique des lésions cutanées avant le traitement et trois jours après.

Cette étude a été effectuée sur 360 snips (hanches, mollets, chevilles) provenant de 30 onchocerquiens de Côte-d'Ivoire avant et trois jours après l'administration per os d'une dose thérapeutique d'ivermectine $(200 \mu \mathrm{g} / \mathrm{kg})$. Cette dose a provoqué une disparition quasi-totale des microfilaires intra-lymphatiques et, de façon inattendue, des microfilaires " extra-vasculaires ». L'absence d'aggravation de lésion dermite aiguë après le traitement prouve que l'ivermectine ne provoque pas l'issue de microfilaires dans le tissu conjonctif extra-lymphatique, contrairement à la diéthylcarbama- zine (DEC). La diminution du nombre des microfilaires « extralymphatiques » dans les snips traduit la difficulté de localiser sur les préparations histologiques ces microfilaires, qui sont en fait dans les lymphatiques initiaux. Sous l'effet de l'ivermectine, les microfilaires paralysées seraient refoulées passivement dans le système lymphatique profond sous-cutané et détruites dans les ganglions lymphatiques loco-régionaux sans provoquer d'effets secondaires majeurs au niveau de la peau.

\section{INTRODUCTION}

Since the first communications (Coulaud et al., 1984), the efficiency of ivermectin in microfiladermia was confirmed by multiple studies (Awadzi et al., 1986 in Ghana, Soboslay et al., 1987 in Togo, Prod'hon et al., 1987 in a Forest area in Ivory Coast, etc.). The drug is remarkable

1. This investigation was supported by the Science and Technology for Development Programme of the European Community, Contrat $\mathrm{n}^{\circ}$ TS2-0067-F, by the UNDP/World Bank/WHO Special Programme for Research and Training in Tropical Diseases, $n^{\circ}$ RP 910337 and by the CRDI.

* Unité d'Anatomie et de Cytologie Pathologiques, Hôpital Saint-Michel, 33, rue Olivier-de-Serres, F 75015 Paris.

** OCCGE-Institut Pierre Richet, 01 BP 1500 Bouake, Côted'Ivoire.

*** Laboratoire de Biologie Parasitaire, Protistologie et Helminthologie, CNRS URA, 114, Muséum National d'Histoire Naturelle, 61, rue Buffon, F 75231 Paris Cedex 05.

Accepté le: 9 septembre 1992. in that it produces only minor side-effects (Albiez et al., 1988; Sole et al., 1989; Boussinesq, 1991). In this respect ivermectin differs from diethylcarbamazin (DEC), the microfilaricide used until recently, well known for its adverse effects (« Mazzoti reaction »).

As previously reported (Vuong et al., 1985, 1988), the so-called intra-dermic microfilariae live in fact in the lymphatic vessels. Results from several studies seem to confirm indirectly this claim. Prod'hon et al. (1987) showed that 7 days after treatment there is a decrease of the number of microfilariae in the skin concomittant with a hundredfold decrease in the vector. The suggestion was that, following treatment, the distribution of the microfilariae in the dermis was modified in a way that make them less accessible to the vector. In fact, in an analysis of the vertical distribution of microfilariae, it could be demonstrated that the surviving parasites are localized deeper in the hypodermis (Jurgens and Schulz-Key, 1990). Numerous microfilariae were found in the sub-cutaneous lymph nodes after administration of ivermectin (Duke et al., 1991).

The aim of the present study was to test our earlier 
findings on a large sample of skin-snips (360) from 30 onchocerciasis patients from Ivory Coast taken before and three days after treatment with ivermectin.

\section{MATERIALS AND METHODS}

\section{1 - Treatment}

Thirty onchocerciasis patients, living in a focus of Sudanese savana in the Northern Ivory Coast, were given $200 \mu \mathrm{g} / \mathrm{kg}$ of ivermectin per os.

\section{2 - Parasitological Methods}

- Microfilarial density (arithmetical mean of 2 snips obtained from the iliac crests) was measured in each patient on day 0.

- The number of microfilariae ingested by Simulium damnosum s. 1. from each onchocerciasis patient was assessed by direct counting of the fresh stomacal microfilariae in 2 series of 20 flies, engorged on $\mathrm{D}_{0}$ and $\mathrm{D}_{3}$ and dissected after the blood meal.

\section{3 - Histopathological methods}

Snips from both iliac crests, calves and ankles taken on $\mathrm{D}_{0}$ (6 snips) and $\mathrm{D}_{3}(6$ snips) were fixed in $10 \%$ formalin. Tissues from each patient collected on the same day were embedded together in the same paraffin block, cut at $5 \mu \mathrm{m}$, stained in SafronHematoxylin-Eosin and mounted in Permount. Some sections were also stained with Trichrom with Light Green, Giemsa or Orcein. The snips could be differenciated in the blocks by the thickness of the epidermis (ankle skin), staining with waterproof india ink before embedding (iliac crests skin).

\section{4 - IMMUNOMORPHOLOGICAL METHODS}

Attempts to identify the initial lymphatic vessels were done. The peroxydase-anti-peroxydase technique (PAP) was used on deparaffined sections with vascular endothelial markers (VIII factor, CD34, BNH9) and capillary basement membrane markers (collagen IV, laminin). Six snips obtained from two patients harboring microfilardemia of 45,5 and 195,5 were tested.

\section{RESULTS}

Both parasites and skin lesions were identified and localized according to criteria previously defined (Vuong et al., 1991). Microfilariae were intra-lymphatic or extra-vascular. The lesions belonged either to an inflammatory process or to the so-called « reactive " changes. The inflammatory lesions were of 5 types: chronic non-specific dermatitis (type 1), acute dermatitis (type 2), subacute dermatitis (type 3), granulomatous dermatitis (type 4) and dermal sclerosis (type 5). "Reactive " lesions were of various types: dilation of lymphatic vessels, dilation of blood capillaries, accumulation of mast-cells, accumulation of melanophages, eosinophilic necrosis. Parasites and lesions were quantitated by assigning a score to each parameter as follows: 1-3 microfilariae $=$ score 1 ; 4-6 microfilariae $=$ score 2 ; more than 6 microfilariae $=$ score 3 ; intensity of lesions: $(+)=$ score $1(++)=$ score $2(+++)=$ score 3 .

\section{PARASITOLOGICAL FINGINGS}

At $\mathrm{D}_{0}$, the mean microfilarial density per snip was 93,7 (range: 18-264). The mean number of ingested microfilariae/Sumulium was 15 at $\mathrm{D}_{0}$ and 0.5 at $\mathrm{D}_{3}$.

\section{Pathological FINDINGS}

Skin changes were identical whatever the origin of the snip (iliac crest, calf or ankle). The mean score of microfilarial quantity and of each histological lesion were represented (Fig. 1) at $\mathrm{D}_{0}$ (black columns) and $\mathrm{D}_{3}$ (white columns). There was a considerable decrease in intralymphatic and in " extra-vascular » microfilariae. The types and intensities of the lesions in the tissue remained unchanged. Acute dermatitis (type 2) and granulomatous dermatitis lesions were rare before as well as after treatment. The eosinophilic necrosis of the connective tissue, giving a lizard aspect of the skin, was as frequent before as after treatment. Subacute lymphangitis was observed in the lymphatic capillaries running alongside the blood capillaries. The lymphatic capillaries were infiltrated with neutrophils, mononuclear cells such as lymphocytes and plasma cells; some displayed fibrinous thrombi.

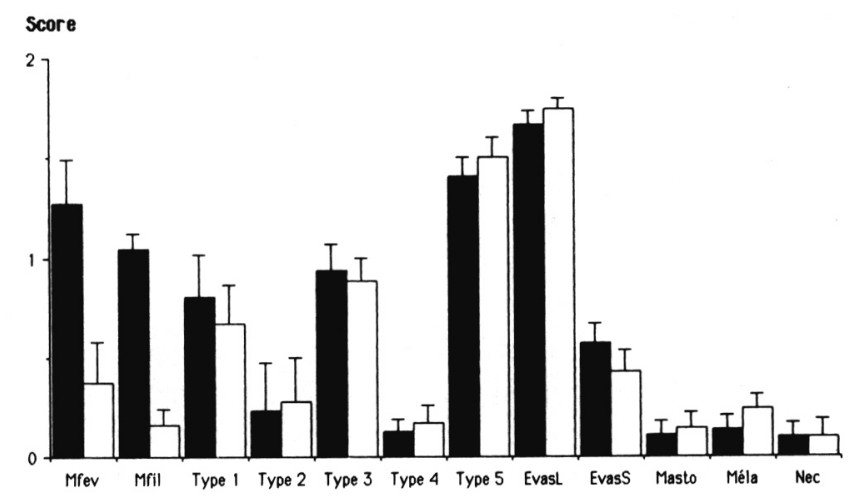

Fig. 1. - Effect of a single oral dose of ivermectin $(200 \mu \mathrm{g} / \mathrm{kg})$ on thirty onchocerciasis patients: results of the histopathological study of 360 skin-snips (from iliac crests, calves and ankles), taken before (black columns) and three days after the treatment (white columns).

Abscissa: mean scores of microfilarial quantity and of each histological lesions. Mfev: extravascular microfilariae; Mfil: intralymphatic microfilariae; Type 1 , Type 2 , Type 3 , Type 4: respectively chronic, acute, subacute, granulomatous dermatitis and Type 5: dermal sclerosis; EvapS: dilation of blood capillaries; EvasL: dilation of lymphatic capillaries; Masto: accumulation of mastocytes; Mela: accumulation of melanonophages; Nec: eosinophilic necrosis of the connective tissue.

\section{IMMUNOMORPHOLOGICAL FINDINGS}

Endothelial lining of lymphatic capillaries containing sections of microfilariae did not show any labelling with VIII factor, CD 34 and BNH 9 while endothelial cells of blood 
capillaries could clearly be identified by these markers. Contrary, the markers of the basement membrane, collagen IV and laminin, were weakly positive around slits containing sections of microfilariae and around blood capillaries.

\section{COMMENT}

This study reconfirms the rapidity of ivermectin's effect on the decrease of microfiladermia, as well as the lack of its secondary dermal effects. The comparison of the number of microfilariae ingested by the Simulium and the one in the snips before $\left(D_{0}\right)$ and after the treatment $\left(D_{3}\right)$ clearly demonstrated this fact. Moreover, this work brought some additional facts:

1 - From the pathological point of view, the lack of intensification of acute inflammatory lesions after treatment, demonstrates that ivermectin did not induce an exit of microfilariae into the extra-lymphatic connective tissue.

2 - The decrease in the number of " extra-lymphatic" microfilariae demonstrates the difficulty to localize microfilariae on histological sections. Some so-called « extra-vascular » microfilariae were in fact inside the initial lymphatic capillaries.

3 - The numerous subacute inflammatory lesions developped around blood capillaries correspond in fact to a lymphangitis of lymphatic capillaries running alongside blood capillaries as described in the Cercopithifilaria johnstoni model (Vuong et al. in press). This lesions is frequently asociated with dilation of lymphatic capillaries which is as prominent before as after treatment.

\section{CONCLUSION}

The rapid drainage of microfilariae towards the deep lymphatic vessels of the skin and into the lymph nodes can be explained as follows: under normal conditions, microfilariae maintain themselves in the lymphatic capillaries of the skin. This is an active phenomenon, because the microfilariae must resist the pressure constanstly exercized by the skin's muscular activity, which tends to push them as the lymph towards the deep lymphatic vessels. Ivermectin rapidly induces muscular changes of microfilariae (Darge et al., 1991). Paralyzed microfilariae are then carried towards the large collecting lymphatic vessels. Thus, the mode of action of ivermectin is totally opposite to the one of diethylcarbamazin. This drug induces a sudden exit of microfilariae from the lymphatic channels, and triggers a synchronous inflammatory process in the peri-vascular connective tissue, a process known as the Mazzotti reaction; microfilariae are then destroyed in the connective tissue (Bain et al., 1987). Under the influence of ivermectin, the microfilariae remain in the lymphatic system and are destroyed inside the lymph nodes, so that no inflammatory process is induced in the connective tissue (skin, sclera, corneal stroma) and the ocular and skin lesions are not intensified.

\section{REFERENCES}

Albiez E. J., Newland H. S., White A. J., Greene B. M., Taylor H. R., Büttner W. D. : Chemotherapy of onchocerciasis with high doses of diethylcarbamazine or a single dose of ivermectin: microfilarial levels and side effects. Tropenmed. Parasitol., 1988, $39, \quad 19-24$.

Awadzi K., Dadzie K. Y., Schulz-Key H., Gilles H. M., Fulford A. J., Aziz M. A. : The chemotherapy of onchocerciasis XI. A double blind comparison of ivermectin, diethylcarbamazine and placebo in human onchocerciasis in northern Ghana. Ann. Trop. Med. Parasitol., 1986, 80, 433-442.

Bain O., Vuong P. N., Petit G., Chabaud A. G., Capron A., Cesbron J. Y. : Modifications cutanées provoquées par une dose de DEC chez des rongeurs à microfilaires dermiques; intérêt de ces phénomènes pour comprendre la réaction de Mazzotti et la pathogénie de l'onchocercose humaine. C. R. Acad. Sci., Paris, 304, 1987, sér. 111, 6, 133-138.

Boussinesq M. : Étude épidémiologique de l'onchocercose en zone de savane camerounaise. Effets d'un traitement de masse par l'ivermectine. Thèse Dr. Sc. Parasitologie, Univ. Sc. et Tech. Languedoc, 4 mars 1991, $426 \mathrm{p}$.

Coulaud J. P., Larivière M., Aziz M. A., Gervais M. C., Gaxotte P., Deluol A. M., Cenac J. : Ivermectin in onchocerciasis. Lancet, 1984, 2, 174-177.

Darge K., Lucius R., Monson M. H., Behrendsen J., Büttner D. W. : Immunomorphological and electron microscopic studies of microfilariae in skin and lymph nodes from onchocerciasis patients after ivermectin treatment. Trop. Med. Parasitol., 1991, 42, 361-367.

Duke B. O. L., Soula G., Zea-Flores G., Bratthauer G. L., Doumbo O. : Migration and death of skin-dwelling Onchocerca volvulus microfilariae after treatment with ivermectin. Trop. Med. Parasitol., 1991, 42, 125-130.

Jurgens S., Schulz-Key H. : Effect of ivermectin on the vertical distribution of Onchocerca volvulus microfilariae in the skin. Trop. Med. Parasitol., 1990, 41, 165-168.

Prod'hon J., Lardeux F., Bain O., Hébrard G., Prud'hon J. M. : Ivermectine et modalités de la réduction de l'infection des simulies dans un foyer forestier d'onchocercose humaine. Ann. Parasitol. Hum. Comp., 1987, 62, 590-598.

Soboslay P. T., Newland H. S., White A. T., Erttmann K. D., Albiez E. J., Taylor H. R., Williams P. N., Greene B. M. : Ivermectin effect on microfilariae of Onchocerca volvulus after a single oral dose in humans. Trop. Med. Parasitol., 1987, 38, 8-10.

Sole G. De, Awadzi K., Remme J., Dadzie K. Y., Ba O., Giese J., Karam M., Keita F. M., Opoku N. O. : A community trial of ivermectin in the onchocerciasis focus of Asubende, Ghana. II. Adverse reactions. Trop. Med. Parasitol., 1989, 40, 375-382.

Vuong-Ngoc P., Bain O., Petit G., Chabaud A. G. : Étude comparative des lésions cutanées et oculaires du muridé Lemniscomys striatus, parasité par Monanema spp. et d'Atherurus africanus, parasité par Cercopithifilaria sp., avec celles de l'onchocercose humaine. C. R. Acad. Sci., Paris, 301, 1985, sér. III, 9, 433-435.

Vuong-Ngoc P., Bain O., Cabaret J., Petit G., Prod'hon J., Ranque Ph., Chabaud A. G. : Forest and savanna onchocerciasis: comparative morphometric histopathology of skin lesions. Trop. Med. Parasitol., 1988, 39, 105-110.

Vuong P. N., Wanji S., Sakka L., Kläger S., Bain O. : The murid filaria monanema martini: a model for onchocerciasis. Part I. - Description of lesions. Ann. Parasitol. Hum. Comp., 1991, 66, 109-120.

Vuong P. N., Spratt D. M., Wanji S., Aimard L., Bain O. : Onchocerca-like lesions induced by the filaria Cercopithifilaria johnstoni in its natural hosts and in the white rat. Int. J. Parasitol., in press. 